\title{
Front Matter: Volume 11809
}

, "Front Matter: Volume 11809," Proc. SPIE 11809, Organic, Hybrid, and Perovskite Photovoltaics XXII, 1180901 (21 September 2021); doi: $10.1117 / 12.2606629$

SPIE Event: SPIE Organic Photonics + Electronics, 2021, San Diego, California, SPIE. United States 


\section{PROCEEDINGS OF SPIE}

\section{Organic, Hybrid, and Perovskite Photovoltaics XXII}

\section{Zakya H. Kafafi}

Paul A. Lane

Editors

1-5 August 2021

San Diego, California, United States

Sponsored and Published by

SPIE 
The papers in this volume were part of the technical conference cited on the cover and title page. Papers were selected and subject to review by the editors and conference program committee. Some conference presentations may not be available for publication. Additional papers and presentation recordings may be available online in the SPIE Digital Library at SPIEDigitalLibrary.org.

The papers reflect the work and thoughts of the authors and are published herein as submitted. The publisher is not responsible for the validity of the information or for any outcomes resulting from reliance thereon.

Please use the following format to cite material from these proceedings:

Author(s), "Title of Paper," in Organic, Hybrid, and Perovskite Photovoltaics XXII, edited by Zakya H. Kafafi, Paul A. Lane, Proc. of SPIE 11809, Seven-digit Article CID Number (DD/MM/YYYY); (DOI URL).

ISSN: 0277-786X

ISSN: 1996-756X (electronic)

ISBN: 9781510644564

ISBN: 9781510644571 (electronic)

Published by

SPIE

P.O. Box 10, Bellingham, Washington 98227-0010 USA

Telephone +1 3606763290 (Pacific Time)

SPIE.org

Copyright @ 2021 Society of Photo-Optical Instrumentation Engineers (SPIE).

Copying of material in this book for internal or personal use, or for the internal or personal use of specific clients, beyond the fair use provisions granted by the U.S. Copyright Law is authorized by SPIE subject to payment of fees. To obtain permission to use and share articles in this volume, visit Copyright Clearance Center at copyright.com. Other copying for republication, resale, advertising or promotion, or any form of systematic or multiple reproduction of any material in this book is prohibited except with permission in writing from the publisher.

Printed in the United States of America by Curran Associates, Inc., under license from SPIE.

Publication of record for individual papers is online in the SPIE Digital Library.

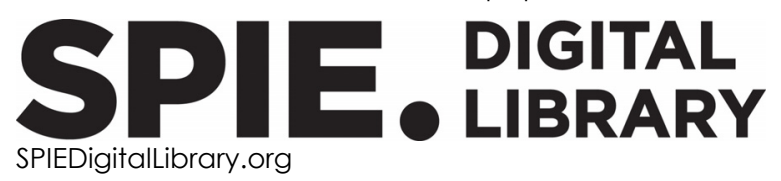

Paper Numbering: A unique citation identifier (CID) number is assigned to each article in the Proceedings of SPIE at the time of publication. Utilization of CIDs allows articles to be fully citable as soon as they are published online, and connects the same identifier to all online and print versions of the publication. SPIE uses a seven-digit CID article numbering system structured as follows:

- The first five digits correspond to the SPIE volume number.

- The last two digits indicate publication order within the volume using a Base 36 numbering system employing both numerals and letters. These two-number sets start with 00, 01, 02, 03, 04, 05, 06, 07, 08, 09, OA, OB ... 0Z, followed by 10-1Z, 20-2Z, etc. The CID Number appears on each page of the manuscript. 


\section{Contents}

FUNDAMENTALS OF ORGANIC AND PEROVSKITE SOLAR CELLS

11809 OD Density functional theory analysis of perovskite at ambient temperature [1 1809-20]

PERFORMANCE \& STABILITY OF ORGANIC AND PEROVSKITE SOLAR CELLS I

$11809 \mathrm{OH} \quad$ Lessons learned from the first outdoor test of perovskite/silicon tandem solar cells [1 1809-24]

PEROVSKITE MODULES AND NOVEL CONCEPTS

11809 OU Solution-processable organic photodiodes with high detectivity and thermal stability designed for visible or near-infrared CMOS image sensors [1 1809-40]

PROCESSING OF ORGANIC AND PEROVSKITE SOLAR CELLS

1180910 The potential benefits of polyethylenimine as an electron extraction layer for facilitating the manufacturing of inverted organic solar cells [1 1809-48] 
Proc. of SPIE Vol. 11809 1180901-4

\section{Downloaded From: https://www.spiedigitallibrary.org/conference-proceedings-of-spie on 25 Apr 2023
Terms of Use: https://www.spiedigitallibrary.org/terms-of-use}

